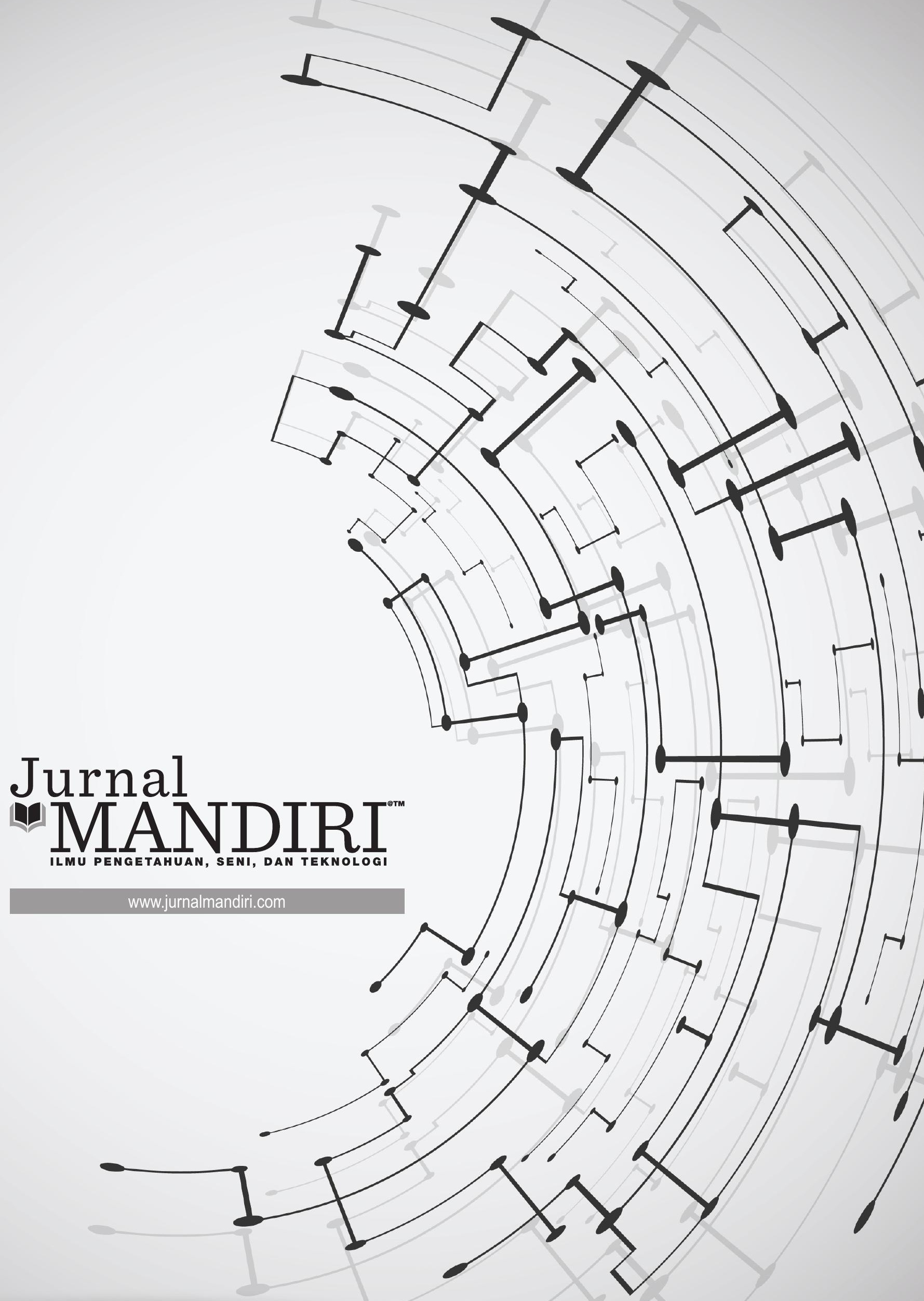


ISSN : 2580-3220, E-ISSN : 2580-4588

J. Mandiri., Vol. 3, No. 2, Desember 2019 (170 - 182)

C2018 Lembaga Kajian Demokrasi

dan Pemberdayaan Masyarakat (LKD-PM)

DOI : https://doi.org/10.33753/mandiri.v3i2.73

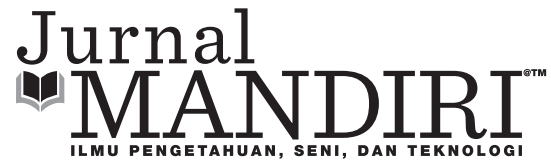

\title{
Pengaruh Disiplin dan Motivasi Terhadap Kinerja Karyawan Pada SMK Sasmita Jaya I Pamulang
}

\author{
Sri Sukapti \\ Fakultas Ekonomi, Universitas Pamulang \\ cungsri2425@gmail.com
}

\begin{abstract}
Abstrak
Tujuan penelitian ini untuk mengetahui apakah terdapat pengaruh positif dan signifikan disiplin terhadap kinerja karyawan, apakah terdapat pengaruh positif dan signifikan motivasi terhadap kinerja karyawan dan apakah terdapat pengaruh positif dan signifikan disiplin dan motivasi terhadap kinerja karyawan secara simultan kepada karyawan SMK Sasmita Jaya I Pamulang. Metode yang digunakan dalam penelitian ini deskriptif kuantitatif dengan teknik survei. Instrumen pengumpul data yang digunakan adalah kuesioner tertutup dengan skala likert dengan jumlah populasi sebanyak 110 orang karyawan, dengan sampel responden sebanyak 110 orang karyawan pada SMK Sasmita Jaya I Pamulang. Data dianalisis dengan menggunakan metode statistik dengan program SPSS versi 23 for windows. Hasil dari penelitian ini menunjukkan bahwa : (1) Hasil pengujian hipotesis disiplin menunjukkan nilai $t_{\text {hiturg }}$ sebesar 9,044 yang kemudian dibandingkan dengan $t_{\text {tabel }}$ yaitu 1,982 , yang berarti bahwa hipotesis dalam penelitian ini menolak $H_{0}$ dan menerima $H^{a}$. Dengan demikian dapat disimpulkan bahwa hipotesis H1 "Disiplin mempunyai pengaruh positif dan signifikan terhadap Kinerja karyawan" diterima. (2) Hasil pengujian hipotesis motivasi menunjukkan nilai $t_{\text {hitung }}$ sebesar 8,698 yang kemudian dibandingkan dengan $t_{\text {tabel }}$ yaitu 1,982, yang berarti bahwa hipotesis dalam penelitian ini menolak $H_{o}$ dan menerima $H_{a}$. Dengan demikian dapat disimpulkan bahwa hipotesis H2 "Motivasi mempunyai pengaruh positif dan signifikan terhadap Kinerja karyawan" diterima. (3) Hasil perhitungan statistik menunjukkan nilai $F_{\text {hitung }}=85,186$ yang kemudian dibandingkan dengan $F_{\text {tabel }}$ yaitu 3,08, yang berarti bahwa hipotesis dalam penelitian ini menolak $H_{o}$ dan menerima $H_{a}$. Dengan demikian dapat disimpulkan bahwa hipotesis H3 "Disiplin dan Motivasi mempunyai pengaruh positif dan signifikan secara simultan terhadap terhadap Kinerja karyawan" diterima.
\end{abstract}

Kata Kunci : Disiplin, Motivasi dan Kinerja Karyawan

\begin{abstract}
The purpose of this research is to find out whether there is a positive and significant effect of discipline on employee performance, to find out whether there is a positive and significant effect on motivation on employee performance and to find out whether there is a positive and significant influence of discipline and motivation on employee performance simultaneously. This research was conducted to employees of SMK Sasmita Jaya I Pamulang. This research uses quantitative descriptive methods with survey techniques. The data collection instrument used was a closed questionnaire with a Likert scale with a population of 110 employees, with a sample of respondents as many as 110 employees in SMK Sasmita Jaya I Pamulang. Data were analyzed using statistical methods with SPSS version 23 for windows. The results of this study indicate that: (1) The results of the disciplinary hypothesis test show a $t_{\text {value }}$ of 9.044 which is then compared with $t_{\text {table }}$ of 1.982 , which means that the hypothesis in this study rejects $H_{o}$ and accepts $H_{a}$. Thus it can be concluded that the H1 hypothesis "Discipline has a positive and significant effect on employee performance" is accepted. (2) The results of testing
\end{abstract}


the motivation hypothesis show the $t_{\text {value }}$ of 8.698 which is then compared with the $t_{\text {table }}$ of 1.982, which means that the hypothesis in this study rejects $H_{o}$ and accepts $H_{a}$. Thus it can be concluded that the H2 hypothesis "Motivation has a positive and significant effect on employee performance" is accepted. (3) The results of statistical calculations show the calculated $F_{\text {value }}=85.186$ which is then compared to the $F_{\text {table }}$ of 3.08 , which means that the hypothesis in this study rejects $H_{o}$ and accepts $H_{a}$. Thus it can be concluded that the H3 hypothesis "Discipline and Motivation have a positive and significant effect simultaneously on employee performance" is accepted.

Keywords : Discipline, Motivation and Employee Performance

\section{PENDAHULUAN}

Dunia pendidikan memegang peranan penting dalam menghasilkan sumber daya manusia Indonesia. Peran ini terkait dengan upaya menjadikan generasi penerus bangsa sebagai manusia-manusia cerdas, kreatif, dan inovatif serta berkarater kuat dalam konteks pendidikan dan pembelajaran. Salah satu institusi yang paling efektif guna mengembangkan potensi dan bakat yang dimiliki oleh peserta didik, baik secara akademik maupun teori terapan adalah sekolah. Sekolah merupakan salah satu lembaga pada jalur pendidikan formal yang dirancang dan diselenggarakan untuk mendidik peserta didik melalui bimbingan yang diberikan oleh tenaga pendidik. Sebagai lembaga yang berada pada jalur pendidikan formal sekolah bertugas untuk mendidik peserta didik agar memiliki keunggulan dan daya saing terhadap kebutuhan dunia kerja melalui jalur pendidikan kejuruan.

Sekolah Menengah Kejuruan (SMK) adalah salah satu bentuk satuan pendidikan formal yang menyelenggarakan pendidikan kejuruan pada jenjang pendidikan menengah atas sebagai lanjutan dari Sekolah Menengah Pertama (SMP) atau bentuk lain yang sederajat yang diakui pemerintah.

SMK Sasmita Jaya 1 Pamulang merupakan sebuah intitusi penyelenggara pendidikan menengah kejuruan yang berada diwilayah Tangerang Selatan dibawah naungan Yayasan Sasmita Jaya. Yayasan Sasmita Jaya juga menaungi beberapa lembaga pendidikan antara lain SMK Sasmita Jaya 1, SMK Sasmita Jaya 2 dan Universitas Pamulang.

Kualitas pendidikan akan dapat dicapai dengan baik apabila didukung oleh kompetensi dan kinerja yang baik dari seorang tenaga pendidik. Seorang tenaga pendidik dituntut untuk memberikan kinerja optimalnya dalam memberikan pelayanaan berupa pengajaran bagi peserta didik, salah satu faktor yang dapat mempengaruhi kinerja dari seorang pendidik adalah disiplin.

Disiplin adalah sikap kesedian dan kerelaan seseorang untuk mematuhi dan menaati normanorma peraturan yang berlaku disekitarnya.

Permasalahan yang terjadi terkait disiplin karyawan pada SMK Sasmita Jaya 1 Pamulang adalah sering dijumpainya keterlambatan dalam melakukan absensi kerja dan keterlambatan saat masuk kerja, hal ini membuktikan bahwa ketaatan karyawan akan peraturan dan tata tertib yang berlaku masih kurang baik, belum optimalnya sikap teladan berdisiplin kerja yang dicontohkan pemimpin, kurangnya pengawasan langsung dari pimpinan, kurang adilnya sanksi bagi pelanggaran yang terjadi terkait disiplin yang dapat menimbulkan efek jera. Faktor lain yang juga mempengaruhi kinerja karyawan pada SMK Sasmita Jaya 1 Pamulang adalah faktor motivasi. Motivasi merupakan dorongan yang tumbuh dalam diri seseorang, baik yang berasal dari dalam maupun luar diri untuk melakukan pekerjaan.

Permasalahan yang terjadi terkait motivasi pada SMK Sasmita Jaya 1 Pamulang adalah terkait keterbatasan sarana dan fasilitas pendukung kerja di mana masih terdapat beberpa fasilitas kerja yang kurang baik seperti keterbatasan komputer dan printer untuk karyawan serta terbatasnya AC untuk penyejuk ruangan.

Kinerja adalah hasil kerja (output), baik secara kualitas maupun secara kuantitas yang berhasil dicapai oleh para karyawan. Lebih lanjut menurut Rivai dan Basri dalam Sinambela (2012:6), kinerja adalah hasil atau tingkat keberhasilan seseorang atau kelompok dalam suatu periode tertentu di- 
dalam melaksanakan tugas dibandingkan dengan berbagai kemungkinan seperti hasil kerja, target atau kriteria yang telah ditentukan terlebih dahulu dan telah disepakati bersama.

Permasalahan yang terjadi pada terkait kinerja karyawan pada SMK Sasmita Jaya 1 Pamulang adalah terkait keterlambatan karyawan dalam menyelesaikan tugas yang menjadi tanggung jawab kerjanya, disisi lain beban pekerjaan yang berlebih kerap kali menimbulkan kelelahan pada diri karyawan sehingga sering kali pekerjaan yang menjadi tanggung jawab diselesaikan dengan kurang optimal oleh karyawan, permasalahan lain adalah kurangnya kreativitas karyawan dalam melakasanakan pekerjaan, disertai dengan kurangnya loyalitas kerja yang dimiliki oleh karyawan, masalah lainnya adalah kerap terjadinya perbedaan pendapat yang terjadi diantara para karyawan akibat kurang harmonisnya hubungan kerja yang terjalin diantara para karyawan yang berkerja pada SMK Sasmita Jaya 1 Pamulang.

Berdasarkan fakta dan permasalah terkait belum optimalnya kinerja karyawan pada SMK Sasmita Jaya 1 Pamulang yang disebabkan oleh berbagai faktor diantaranya seperti disiplin dan motivasi yang telah penulis kemukakan diatas, maka penulis merasa tertarik dan berkeyakinan untuk melakukan penelitian dengan judul: Pengaruh Disiplin dan Motivasi Terhadap Kinerja Karyawan Pada SMK Sasmita Jaya 1 Pamulang.

Penelitian sebelumnya telah dilakukan oleh Ahmad Nazir di dalam Jurnal Mandiri Vol 3 No 12018 yang berjudul pengaruh pelatihan dan disiplin kerja terhadap kinerja karyawan pada PT Surya Mustika Nusantara dengan hasil Pengaruh Disiplin $\left(\mathrm{X}_{2}\right)$ Terhadap Kinerja karyawan (Y) menujukan adanya pengaruh yang positif dan signifikan antara Disiplin $\left(\mathrm{X}_{2}\right)$ Terhadap Kinerja karyawan (Y). Jadi bila Disiplin $\left(\mathrm{X}_{2}\right)$ meningkat/ ditingkatkan hingga mendapat nilai 1, maka Kinerja karyawan $(\mathrm{Y})$ menjadi : $\hat{Y}=51.769+0.125$ $.1=52.894$. Jadi diperkirakan Kinerja karyawan akan meningkat sebesar 52.894. Dengan demikian, Kinerja karyawan akan naik, bila Pelatihan lebih meningkat. Jadi penelitian yang dilakukan sebelumnya sebagai acuan di dalam melakukan penelitian ini.

\section{METODE}

Penelitian ini dilaksanakan di SMK Sasmita Jaya 1 Pamulang yang bertempat di Jalan Surya Kencana No. 2 Pamulang Barat, Pamulang, Tangerang Selatan. Waktu penelitian dilaksanakan pada bulan April 2017 hingga pada bulan Juni 2017.

Metode penelitian yang digunakan dalam penelitian ini adalah metode statistik deskriptifkuantitatif, yang menekankan pada analisis data numerical (angka) yang diolah dengan metode statistika, sementara bentuk rumusan hipostesisnya menggunak rumusan hipotesis deskriptif. Hipotesis deskriptif adalah dugaan tentang nilai suatu variabel mandiri, dan tidak membuat perbandingan atau hubungan, Sugiyono (2013:86).

Desain penelitian diawali dengan studi pendahuluan yang bertujuan untuk mengidentifikasi fakta dan masalah yang terdapat dan terjadi di tempat penelitian, dan dilanjutkan dengan menyusun kerangka penelitian serta menetapkan hipotesis penelitian. Secara rinci alur disain penelitian ini dapat dilihat pada gambar berikut dibawah :

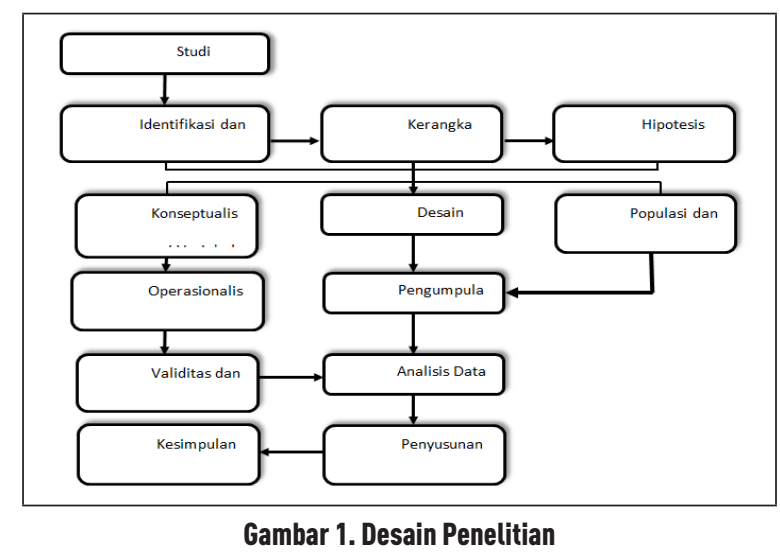

\section{Teknik Penentuan Data}

(Populasi dan Sampel Penelitian)

Sugiyono (2013:157), memberikan pengertian populasi adalah wilayah generalisasi yang terdiri dari obyek atau subyek yang mempunyai kuantitas dan karakteristik tertentu yang ditetapkan oleh peneliti untuk dipelajari dan kemudian ditarik kesimpulannya. Populasi penelitian yang dimaksud adalah seluruh karyawan yang bekerja pada SMK Sasmita Jaya 1 Pamulang yang berjumlah 110 orang. 
Sampel adalah sebagian dari jumlah dan karakterisitik yang dimiliki oleh populasi tersebut. Teknik pengambilan sampel yang digunakan dalam penelitian ini adalah sampling jenuh atau lebih dikenal dengan istilah sensus. Hal ini mengacu pada pendapat Suharsimi Arikunto yang menyatakan bahwa apabila subyek kurang dari 100 , lebih baik diambil semuanya sehingga penelitiannya merupakan penelitian populasi.

Berdasarkan data penelitian yang diperoleh dari bagian kepegawaian pada SMK Sasmita Jaya 1 Pamulang, jumlah karyawan yang dimiliki adalah sebanyak 110 orang karyawan. Oleh karena itu seluruh karyawan akan dijadikan sampel dalam penelitian.

Opersaional variabel adalah suatu definisi yang memberikan penjelasan atas suatu variabel dalam bentuk yang dapat diukur. Definisi operasional ini memberikan informasi yang diperlukan untuk mengukur variabel yang akan diteliti.

Disiplin adalah sikap kesedian dan kerelaan seseorang untuk mematuhi dan menaati normanorma peraturan yang berlaku di sekitarnya.

Disiplin adalah sikap kesedian dan kerelaan seseorang untuk mematuhi dan menaati normanorma peraturan yang berlaku disekitarnya. Skor disiplin diperoleh berdasarkan jawaban responden terhadap instrumen dengan dimensi sebagai berikut :

1. Teladan Pemimpin

2. Balas Jasa

3. Ketaatan

4. Pengawasan

5. Ketegasan

Instrumen yang digunakan dalam mengukur variabel disiplin adalah sebanyak 10 butir pernyataan. Kisi- kisi intrumen disiplin kerja dapat di lihat pada tabel 2 berikut :

\begin{tabular}{|c|c|c|c|c|}
\hline \multicolumn{5}{|c|}{ Tabel 2. Kisi-Kisi Instrumen Disiplin } \\
\hline VARIABEL & KONSEP VARIABEL & INDIKATOR & NOMOR BUTIR & JUMLAH \\
\hline \multirow{5}{*}{$\begin{array}{c}\text { Disiplin } \\
\left(X_{1}\right)\end{array}$} & \multirow{5}{*}{$\begin{array}{l}\text { Disiplin adalah sikap } \\
\text { kesediaan dan kerelaan } \\
\text { seseorang untuk mematuhi } \\
\text { dan menaati norma-norma } \\
\text { peraturan yang berlaku } \\
\text { disekitarnya }\end{array}$} & $\begin{array}{l}\text { Teladan } \\
\text { Pimpinan }\end{array}$ & 1,2 & 2 \\
\hline & & Balas Jasa & 3,4 & 2 \\
\hline & & Ketaatan & 5,6 & 2 \\
\hline & & Pengawasan & 7,8 & 2 \\
\hline & & Ketegasan & 9,10 & 2 \\
\hline \multicolumn{4}{|c|}{ Jumlah Keseluruhan } & 10 \\
\hline \multicolumn{5}{|c|}{ Sumber :Data Hasil Olahan } \\
\hline
\end{tabular}

Definisi konseptual variabel motivasi yaitu, dorongan yang tumbuh dalam diri seseorang, baik yang berasal dari dalam maupun luar diri seseorang untuk melakukan pekerjaan dengan semangat tinggi menggunakan semua kemampuan dan keterampilan yang dimilikinya.

Definisi operasional variabel motivasi yaitu, dorongan yang tumbuh dalam diri seseorang, baik yang berasal dari dalam maupun luar diri seseorang untuk melakukan pekerjaan dengan semangat tinggi menggunakan semua kemampuan dan keterampilan yang dimilikinya. Skor disiplin diperoleh berdasarkan jawaban responden terhadap instrumen dengan dimensi sebagai berikut :

1. Kebutuhan Fisiologis

2. Kebutuhan Keamanan

3. Kebutuhan Penghargaan

4. Kebutuhan Berkelompok

Instrumen yang digunakan dalam mengukur variabel motivasi adalah sebanyak 10 butir pernyataan. Kisi- kisi intrumen motivasi kerja dapat di lihat pada tabel 3.2 berikut :

\begin{tabular}{|c|c|c|c|c|}
\hline \multicolumn{5}{|c|}{ Tabel 3.2. Kisi-Kisi Instrumen Motivasi } \\
\hline VARIABEL & KONSEP VARIABEL & INDIKATOR & NOMOR BUTIR & JUMLAH \\
\hline \multirow{4}{*}{$\begin{array}{c}\text { Motivasi } \\
\left(X_{2}\right)\end{array}$} & \multirow{4}{*}{$\begin{array}{l}\text { Motivasi dorongan } \\
\text { yang tumbuh dalam diri } \\
\text { seseorang, baik yang berasal } \\
\text { dari dalam maupun luar diri } \\
\text { seseorang untuk melakukan } \\
\text { pekerjaan dengan semangat } \\
\text { tinggi menggunakan } \\
\text { semua kemampuan } \\
\text { dan keterampilan yang } \\
\text { dimilikinya }\end{array}$} & $\begin{array}{l}\text { Kebutuhan } \\
\text { Fisiologis }\end{array}$ & $1,2,3$ & 3 \\
\hline & & $\begin{array}{l}\text { Kebutuhan } \\
\text { Rasa Aman }\end{array}$ & 4,5 & 2 \\
\hline & & $\begin{array}{l}\text { Kebutuhan } \\
\text { Penghargaan }\end{array}$ & $6,7,8$ & 3 \\
\hline & & $\begin{array}{l}\text { Kebutuhan } \\
\text { Berkelom- } \\
\text { pok }\end{array}$ & 9,10 & 2 \\
\hline \multicolumn{4}{|c|}{ Jumlah Keseluruhan } & 10 \\
\hline \multicolumn{5}{|c|}{ Sumber :Data Hasil Olahan } \\
\hline
\end{tabular}

Kinerja adalah hasil kerja secara kualitas dan kuantitas yang dicapai seseorang pegawai dalam melaksanakan tugasnya sesuai dengan tanggung jawab yang diberikan.

Kinerja adalah hasil kerja secara kualitas dan kuantitas yang dicapai seseorang pegawai dalam melaksanakan tugasnya sesuai dengan tanggung jawab yang diberikan. Skor kinerja diperoleh berdasarkan jawaban responden terhadap instrumen dengan dimensi sebagai berikut :

1. Kualitas

2. Kuantitas

3. Ketepatan waktu 
4. Efektivitas

5. Kemandirian

Instrumen yang digunakan dalam mengukur variabel kinerja adalah sebanyak 10 butir pernyataan. Kisi-kisi intrumen kinerja dapat di lihat pada tabel 3 berikut :

\begin{tabular}{|c|c|c|c|c|}
\hline \multicolumn{5}{|c|}{ Tabel 3. Kisi-Kisi Instrumen Kinerja } \\
\hline VARIABEL & KONSEP VARIABEL & INDIKATOR & NOMOR BUTIR & JUMLAH \\
\hline \multirow{5}{*}{ Kinerja (Y) } & \multirow{5}{*}{$\begin{array}{l}\text { Kinerja adalah hasil } \\
\text { kerja secara kualitas dan } \\
\text { kuantitas yang dicapai } \\
\text { seseorang pegawai dalam } \\
\text { melaksanakan tugasnya } \\
\text { sesuai dengan tanggung } \\
\text { jawab yang diberikan }\end{array}$} & Kualitas & 1,2 & 2 \\
\hline & & Kuantitas & 3,4 & 2 \\
\hline & & $\begin{array}{l}\text { Ketepatan } \\
\text { waktu }\end{array}$ & 5,6 & 2 \\
\hline & & Efektivitas & 7,8 & 2 \\
\hline & & Kemandirian & 9,10 & 2 \\
\hline \multicolumn{4}{|c|}{ Jumlah Keseluruhan } & 10 \\
\hline
\end{tabular}

Data primer adalah data yang dikumpulkan oleh peneliti dari responden dan diperoleh secara langsung melalui penyebaran angket atau kuesioner pada tempat penelitian yaitu pada SMK Sasmita Jaya 1 Pamulang

Data Sekunder adalah data yang dikumpulkan oleh peneliti yang diperoleh secara langsung melalui buku-buku, literatur kepustakaan seperti laporan-laporan, majalah dan bahan hasil kuliah dan jurnal penelitian ilmiah.

Wawancara adalah sebuah metode yang dilakukan dengan cara mengajukan pertanyaan terkait hal-hal yang ingin diteliti kepada pihak responden dalam penelitian.

Kuesioner adalah sebuah metode yang dilakukan dengan cara mengajukan pertanyaan kepada responden penelitian dalam bentuk angket yang berisi daftar pertanyaan. Angket tersebut diberikan kepada responden dengan harapan seluruh responden menjawab pertanyaan dalam angket sesuai dengan presepsi dari masing-masing responden terhadap butir pernyataan yang terdapat didalam angket penelitian. Angket yang diberikan kepada responden penelitian ini adalah angket yang bersifat langsung dan tertutup, artinya angket tersebut langsung diberikan kepada responden dan reponden dapat memilih salah satu dari alternaatif jawaban yang tersedia didalam angket penelitian.

Teknik penentuan data dalam penelitian ini penulis membuat kuesioner dalam bentuk pernyataan untuk disebarkan kepada seluruh karyawan SMK Sasmita Jaya 1 Pamulang sebanyak 86 responden sebagai sampel penelitian.

Setelah dilakukan pengisian instrumen (kuesioner) oleh responden, kemudian peneliti mengumpulkan kembali angket yang telah dijawab oleh responden yang kemudian seluruh jawaban responden akan diolah dan dianalisa, berdasarkan jumlah jawaban dari 3 variabel yang diteliti yaitu Disiplin Kerja $\left(\mathrm{X}_{1}\right)$, Motivasi $\left(\mathrm{X}_{2}\right)$, dan Kinerja Karyawan (Y) dalam bentuk angka.

Selanjutnya dari ke empat variabel penelitian dibuat skala penilaian dengan rentang jawaban 1 sampai dengan 5 dan instrumen dikembangkan berdasarkan indikator yang ada dengan menggunakan skala likert.

Adapun skor penilaian untuk pernyataan positif dan negatif ditunjukan dalam Tabel 4 berikut:

\begin{tabular}{|c|c|c|}
\hline \multicolumn{3}{|c|}{ Tabel 4. Skor Penilaian Pernyataan Positif dan Negatif } \\
\hline \multirow{2}{*}{$\begin{array}{l}\text { ALTERNATIF PILLHAN } \\
\text { JAWABAN PERKYATAAN }\end{array}$} & \multicolumn{2}{|c|}{ SKOR JAWABAN } \\
\hline & PERMYATAAN POSTIIF & PERNYATAAN NEGATIF \\
\hline Sangat Setuju & 5 & 1 \\
\hline Setuju & 4 & 2 \\
\hline Kurang Setuju & 3 & 3 \\
\hline Tidak Setuju & 2 & 4 \\
\hline Sangat Tidak Setuju & 1 & 5 \\
\hline & & Sumber : Ittijanto (2009: : \\
\hline
\end{tabular}

\section{Rancangan Analisis dan Uji Hipotesis Rancangan Analisis}

Agar suatu data yang terkumpul dapat bermanfaat dalam suatu penelitian, maka perlu dilakukan sebuah analisis data. Untuk mengetahui pengaruh disiplin, dan motivasi kerja terhadap kinerja karyawan pada SMK Sasmita Jaya $1 \mathrm{~Pa}$ mulang, penulis terlebih dahulu melakukan rancangan analisis penelitian sebagai berikut :

\section{Uji Kualitas Data \\ Uji Validitas}

Uji validitas digunakan untuk mengetahui apakah instrumen penelitian yang digunakan telah memenuhi persyaratan dilihat dari segi kesahihan atau validitas. Menurut pendapat yang dikemukakan oleh Sugiyono (2009:121), "validitas adalah tingkat kehandalan dan kesahihan 
alat ukur yang digunakan". Instrumen dikatakan valid berarti menunjukkan alat ukur yang dipergunakan untuk mendapatkan data itu valid atau dapat digunakan untuk mengukur apa yang seharusnya diukur.

Teknik untuk mengukur validitas kuesioner adalah dengan menghitung korelasi antar data pada masing-masing pernyataan dengan skor total, dengan memakai rumus korelasi product moment sebagai berikut :

$r_{x y}=\frac{n\left(\sum x y\right)-\left(\sum x\right)\left(\sum y\right)}{\sqrt{\left\{n \sum x^{2}-\left(\sum x\right)\right\}}\left\{n \sum y^{2}-\left(\sum y\right)^{2}\right\}}$

\section{Keterangan :}

$r \quad=$ Koefisien Korelasi

$N=$ Jumlah Subyek

$X=$ Skor Item

$Y=$ Skor Total

$\Sigma X=$ Jumlah Skor Item

$\Sigma Y=$ Jumlah Skor Total

$\Sigma X^{2}=$ Jumlah Kuadrat Skor Item

$\sum Y^{2}=$ Jumlah Kuadrat Skor Total

Menurut Ghozali (2013:52) mengukur validitas dapat dilakukan dengan cara melakukan korelasi antar skor butir pertanyaan dengan skor total konstruk atau variabel. Uji signifikansi dilakukan dengan membandingkan nilai $\mathrm{r}_{\text {hitung }}$ dengan $r_{\text {tabel }}$ untuk (df) $=n-2$, dalam hal ini $n$ adalah jumlah sampel, jadi df yang digunakan adalah 110-2 = 108 dengan alpha sebesar 5\%, maka menghasilkan nilai $r_{\text {tabel }}$ sebesar 0,187 dengan kriteria sebagai berikut:

- Jika nilai Pearson Correlation > 0,187 dinyatakan valid.

- Jika nilai Pearson Correlation < 0,187 dinyatakan tidak valid.

\section{Uji Reliabilitas}

Reliabilitas adalah indeks yang menunjukkan sejauh mana alat pengukur dapat dipercaya atau diandalkan. Bila suatu alat ukur dipakai beberapa kali untuk mengukur gejala yang sama dan hasil pengukuran yang diperoleh relatif konsisten, maka alat pengukur tersebut reliable.

Rumus yang dapat dipergunakan untuk menghitung reabilitas suatu instrumen yaitu :

$$
r_{c a}=\left(\frac{\mathrm{k}}{\mathrm{k}-1}\right)\left(1-\frac{\sum \mathrm{si}}{\mathrm{s}_{\mathrm{t}}}\right)
$$

Keterangan :

$r_{c a}=$ Nilai Realibilitas Instrument (Cronbach alpha)

$K=$ Jumlah Item

$s i=$ Varians Skor Tiap Item

$s_{t} \quad=$ Varians Skor Total

Adapun kriteria yang dipergunakan dalam menentukan reabilitas suatu instrumen mengacu pada pendapat yang dikemukakan oleh Ghozali (2013:47), dimana suatu variabel penelitian dikatakan reliable apabila memenuhi kriteria sebagai berikut:

- Jika Cronbach Alpha >0,7 dinyatakan reliable.

- Jika Cronbach Alpha <0,7 dinyatakan tidak reliable.

\section{Uji Asumsi Klasik}

\section{Uji Normalitas}

Uji normalitas digunakan untuk menguji apakah dalam sebuah model regresi, variabel bebas dan variabel terikat memiliki distribusi sebaran data yang normal atau tidak, menurut pendapat yang diungkapkan oleh Ghozali (2005:73), model regresi yang baik adalah berdistribusi normal atau mendekati normal. Rumus yang dapat dipergunakan untuk mengetahui normal tidaknya data dalam penelitan adalah dengan menggunakan rumus chi kuadrat sebagai berikut:

$$
x^{2}=\sum \frac{(f o-f h)}{f h}
$$

Keterangan :

$x^{2}=$ Chi Kuadrat

$f_{o} \quad=$ Frekuensi yang Diobservasi

$f_{h} \quad=$ Frekuensi yang Diharapkan

Kriteria yang dipergunakan dalam menentukan normal atau tidaknya suatu data penelitian mengacu pada pendapat yang dikemukakan oleh Ghozali (2005:46), dimana data dalam variabel penelitian dikatakan berdistribusi normal apabila memenuhi kriteria sebagai berikut:

- Jika data menyebar disekitar garis diagonal 
dan mengikuti araha garis diagonal, maka model regresi memenuhi normalitas.

- Jika data menyebar jauh dari garis diagonal dan tidak mengikuti arah garis diagonal, maka model regresi tidak memenuhi normalitas. Uji Multikolinieritas

Menurut pendapat yang dikemukakan oleh Imam Gozali (2005:105), uji multikolinearitas bertujuan untuk menguji apakah model regresi ditemukan adanya korelasi antar variabel bebas. Model regresi yang baik seharusnya tidak dijumpai korelasi diantara varibel bebas. Jika variabel bebas saling berkorelasi, maka variabelvariabel ini tidak ortogonal. Variabel ortogonal adalah variabel bebas yang nilai korelasi antar sesama variabel bebas sama dengan nol. Untuk mendeteksi ada tidaknya multikolinearitas di dalam model regresi adalah sebagai berikut :

Nilai $r^{2}$ yang dihasilkan oleh suatu estimasi model regresi sangat tinggi, tetapi secara individual variabel bebas banyak yang tidak signifikan dalam mempengaruhi variabel terikat.

Menganalisis matrik korelasi variabel-variabel bebas, jika diantara variabel bebas ada korelasi yang cukup tinggi (umumnya diatas 0,90), maka hal ini merupakan indikasi adanya multikolinearitas. Tidak adanya korelasi yang tinggi antar variabel bebas tidak lantas berarti bebas dari multikolinearitas. Multikolinearitas dapat disebabkan karena adanya efek kombinasi dua atau lebih variabel bebas.

Multikolinearitas dapat juga dilihat dari tolerance dan lawannya, variance inflation factor (VIF), kedua ukuran ini menunjukkan setiap variabel bebas manakala yang dijelaskan oleh variabel bebas lainnya. Tolerance mengukur variabilitas variabel bebas yang terpilih yang tidak dijelaskan oleh variabel bebas lainnya. Jadi nilai tolerance yang rendah dama dengan nilai (VIF) tinggi, (karena VIF $=1$ /tolerance). Model regresi yang baik selayaknya tidak terjadi multikolinieritas.

Untuk mendeteksi hal tersebut dapat berpedoman kepada :

- Nilai VIF kurang dari 10

- Nilai tolerance lebih besar dari 0,1

\section{Uji Heterokedasitas}

Uji heteroskedastisitas bertujuan untuk menguji apakah dalam sebuah model regresi terjadi ketidaksamaan varians dari residual, dari satu pengamatan ke pengamatan yang lain. Jika varians dari residual dari satu pengamatan kepengamatan yang lain tetap, maka disebut homoskedastisitas dan jika varians berbeda, disebut heteroskedastisitas. Untuk mendeteksi ada tidaknya heteroskedastisitas dapat digunakan metode grafik Scatterplot yang dihasilkan dari output program SPSS versi 23, apabila pada gambar menunjukkan bahwa titik-titik menyebar secara acak serta tersebar baik di atas maupun di bawah angka 0 pada sumbu Y, maka hal ini dapat disimpulkan tidak terjadi adanya heteroskedastisitas pada model uji regresi, Ghozali (2005:150).

\section{Uji Hipotesis}

Uji Hipotesis diperlukan untuk menguji apakah variabel bebas berpengaruh terhadap variabel terikat. Menurut Sugiyono (2014:275), pengertian hipotesis merupakan jawaban sementara terhadap rumusan masalah penelitian, oleh karena itu rumusan maslah penelitian biasanya disusun dengan bentuk kalimat pertanyaan. Dengan demikian hipotesis penelitian dapat diartikan sebagai jawaban yang bersifat sementara terhadap masalah penelitian, sampai terbukti dengan data yang terkumpul dan harus diuji secara empiris.

Tingkat signifikan yang dipilih dalam penelitian ini adalah 5\%, karena merupakan tingkat umum yang digunakan dalalm penelitian sosial. Tingkat signifikan 5\% berarti kemungkinan besar hasil penarikan kesimpulan memiliki probabilitas sebesar 95\%, atau toleransi kesalahan sebesar 5\%, sedangkan untuk menguji diterima atau ditolaknya hipotesis dapat dilakukan dengan cara uji berikut :

\section{Uji Regresi Sederhana}

Regresi sederhana digunakan untuk menguji hipotesis pertama dan kedua, teknik korelasi parsial yang digunakan adalah korelasi pearson. Tujuan uji regresi sederhana ini adalah untuk mengetahui hubungan antara variabel bebas dan 
terikat.

Menurut Sugiyono (2009:182), rumus yang digunakan untuk mengetahui besarnya hubungan atau korelasi antar variabel $\mathrm{X}_{1}$ dan $\mathrm{Y}$, serta variabel $\mathrm{X}_{2}$ dan $\mathrm{Y}$ ini adalah dengan menggunakan rumus sebagai berikut :

$$
Y=a+b X
$$

Dimana nilai $a$ dan $b$ dapat dihitung dengan rumus:

$$
a=\frac{\left(\sum X\right)\left(\sum^{2}\right)-\left(\sum X\right)\left(\sum X Y\right)}{n \sum X^{2}-\left(\sum X\right)^{2}}
$$

$$
b=\frac{n \cdot \sum X Y-\sum X \cdot \sum Y}{n \cdot \sum X^{2}-\left(\sum X\right)^{2}}
$$

Keterangan :

$\mathrm{X}=$ Variabel bebas

$\mathrm{Y} \quad=$ Variabel terikat

$\mathrm{a}=$ Intersep

$\mathrm{b} \quad=$ Koefisien regresi

\section{Uji Regresi Berganda}

Menurut pendapat yang dikemukan oleh Sugiyono (2009:227), analisis regresi dilakukan untuk melakukan prediksi bagaimana perubahan nilai variabel terikat jika nilai variabel bebas dinaikkan atau diturunkan. Rumus yang dapat dipergunakan dalam uji regresi berganda adalah sebagai berikut:

$$
Y=\alpha+\beta_{1} X_{1}+\beta_{2} X_{2}+\varepsilon
$$

Keterangan :

$\mathrm{Y}=$ Kinerja Karyawan

$\alpha=$ Konstanta

$\beta_{1}, \quad=$ Koefisien regresi variabel $\mathrm{X}_{1}$ (Disiplin)

$\beta_{2}=$ Koefisien regresi variabel $\mathrm{X}_{2}$ (Motivasi)

$\mathrm{X}_{1}=$ Disiplin

$\mathrm{X}_{2}=$ Motivasi

$\varepsilon=$ Distrubance Error atau variabel penggangu

\section{Uji Parsial t}

Menurut Ghozali (2005:90) uji t dilakukan untuk mengetahui besarnya pengaruh masingmasing variabel independen secara individual terhadap variabel dependen. Berikut rumus yang digunakan :

$$
t=r \frac{\sqrt{n-2}}{\sqrt{1-r^{2}}}
$$

Keterangan:

$t=$ Probabilitas

$r \quad=$ Koefesien korelasi

$n \quad=$ Jumlah sampel

Dengan menggunakan rumus diatas, agar dapat ditarik kesimpulan dari hipotesis maka hasil perhitungan statistik uji $\mathrm{t}\left(\mathrm{t}_{\text {hitung }}\right)$ dibandingkan dengan $\left(\mathrm{t}_{\text {tabel }}\right)$ dengan tingkat signifikansi (5\%) atau 0,05 dan derajat bebas $n-3$

Kriteria penerimaan dan penolakan hipotesis yang diajukan adalah sebagai berikut :

- Jika $\mathrm{t}_{\text {hitung }}>\mathrm{t}_{\text {tabel }}$ pada $\mathrm{a}=5 \%$ maka $\mathrm{H}_{\mathrm{o}}$ ditolak dan $\mathrm{H}_{\mathrm{a}}$ diterima

- Jika $\mathrm{t}_{\text {hitung }}>\mathrm{t}_{\text {tabel }}$ pada $\mathrm{a}=5 \%$ maka $\mathrm{H}_{\mathrm{o}}$ diterima dan $\mathrm{H}_{\mathrm{a}}$ ditolak

Kesimpulan mengenai diterima atau tidaknya hipotesis setelah membandingkan antara $\mathrm{t}_{\text {hitung }}$ dan $t_{\text {tabel }}$ dengan hipotesis sebagai berikut :

Variabel $\mathrm{X}_{1}$ (Disiplin)

$\mathrm{H}_{\mathrm{o}}: \rho_{1}=0$ Disiplin tidak berpengaruh positif dan signifikan terhadap kinerja karyawan

$\mathrm{H}_{\mathrm{a}}: \rho_{1} \neq 0$ Disiplin berpengaruh positif dan signifikan kinerja karyawan

Variabel $\mathrm{X}_{2}$ (Motivasi Kerja)

$\mathrm{H}_{\mathrm{o}}: \rho_{2}=0$ Motivasi kerja tidak berpengaruh positif dan signifikan terhadap kinerja karyawan

$\mathrm{H}_{\mathrm{a}}: \rho_{2} \neq 0$ Motivasi kerja berpengaruh positif dan signifikan kinerja karyawan

\section{Uji Simultan F}

Uji F digunakan untuk mengetahui ada atau tidaknya pengaruh bersama (simultan) variabel disiplin, motivasi terhadap kinerja karyawan. Menurut Ghozali (2005:98), uji F dilakukan untuk mengetahui pengaruh variabel-variabel independen secara simultan (bersama-sama) 
terhadap variabel dependen. Untuk menguji ada atau tidaknya hubungan antar variabel bebas $\left(\mathrm{X}_{1}\right.$ dan $\mathrm{X}_{2}$ ) secara simultan berpengaruh terhadap varibel terikat (Y) dilakukan perhitungan dengan menggunakan rumus sebagai berikut :

$$
F \text { hitung }=\frac{\frac{R^{2}}{k}}{\left[\frac{1-R^{2}}{n-k-1}\right]}
$$

Keterangan :

$\mathrm{R}^{2}=$ koefisien korelasi ganda

$\mathrm{k}=$ jumlah variabel bebas

$\mathrm{n} \quad=$ jumlah data

Untuk menguji adanya hubungan antara varibel bebas $\left(\mathrm{X}_{1}\right.$ dan $\left.\mathrm{X}_{2}\right)$, secara simultan berpengaruh terhadap varibel terikat $(\mathrm{Y})$ maka pengujian dilakukan dengan menggunakan uji statistik F dengan langkah-langkah sebagai berikut :

- Menentukan hipotesis secara simultan atau keseluruhan antara varibel bebas (disiplin, dan motivasi) terhadap variabel terikat (kinerja karyawan).

- Menentukan nilai signifikansi yang dipilih yaitu sebesar 5\% atau 0,05 dan derajat bebas $(\mathrm{df}=\mathrm{n}-3)$, untuk mengetahui daerah F tabel sebagai batas daerah penolakan, adapun rumusan hipotesisnya yaitu sebagai berikut ini:

$\mathrm{H}_{\mathrm{o}}: \rho_{1,2}=0$ Tidak terdapat pengaruhpositif dan signifikan secara simultan antara disiplin, dan motivasi terhadapkinerja karyawan

$\mathrm{H}_{\mathrm{a}}: \rho_{1,2} \neq 0$ Terdapat pengaruh positif dan signifikan secara simultan antara disiplin, dan motivasi terhadap kinerja karyawan

Selanjutnya untuk menguji koefesien regresi secara keseluruhan atau secara simultan berdampak terhadap variabel terikat, dapat dilakukan dengan membandingkan $\mathrm{F}_{\text {hitung }}$ dengan $\mathrm{F}_{\text {tabel }}$.

Adapun kriteria penerimaan dan penolakan hipotesis yang telah diajukan adalah sebagai berikut :

- Jika $\mathrm{F}_{\text {hitung }}>\mathrm{F}_{\text {tabel }}$ maka $\mathrm{H}_{\mathrm{o}}$ diterima dan $\mathrm{H}_{\mathrm{a}}$ ditolak

- Jika $\mathrm{F}_{\text {hitung }}>\mathrm{F}_{\text {tabel }}$ maka $\mathrm{H}_{\mathrm{o}}$ ditolak dan $\mathrm{H}_{\mathrm{a}}$ diterima
Kriteria pengambilan keputusan hipotesis dilakukan pada tingkat signifikansi (level of significant) $5 \%$ atau 0,05

\section{Uji Koefeisien Determinasi}

Menurut Ghozali (2005:102) koefisien determinasi $(\mathrm{KD})$ bertujuan untuk mengetahui seberapa besar kemampuan variabel independen menjelaskan variabel dependen.

Untuk mengetahui besarnya kontribusi varibel $\left(\mathrm{X}_{1}\right.$ dan $\left.\mathrm{X}_{2}\right)$ terhadap varibel terikat $(\mathrm{Y})$, dapat dihitung menggunakan rumus sebagai berikut :

$$
K D=r^{2} \times 100 \%
$$

Keterangan :

$K D=$ Koefisien determinasi

$r \quad=$ Koefisien korelasi

Besar kecilnya nilai koefesien determinasi, menunjukkan besar kecilnya kontribusi atau sumbangan variabel bebas $\left(\mathrm{X}_{1}\right.$ dan $\left.\mathrm{X}_{2}\right)$ terhadap varibel terikat $(\mathrm{Y})$.

\section{HASIL dan PEMBAHASAN}

Hasil

Berdasarkan persamaan regresi berganda yang terbentuk dapat disimpulkan bahwa : Variabel disiplindan variabel motivasi mempunyai koefisien yang bertanda positif terhadap variabel kinerja karyawan. Koefisien variabel disiplin memberikan nilai sebesar 0,485 yang berarti bahwa, jika variabel disiplin semakin baik dengan asumsi variabel lain tetap maka kinerja karyawan akan mengalami peningkatan. Koefisien variabel motivasi memberikan nilai sebesar 0,461yang berarti bahwa jika motivasi semakin baik dengan asumsi variabel lain tetap maka kinerja karyawan akan mengalami peningkatan.

Uji t (Parsial) bahwa hasil pengujian hipotesis disiplin menunjukkan nilai $t$ hitung sebesar 9,044 lebih tinggi dari nilai $t_{\text {tabel }}$ yaitu 1,982. Taraf signifikansi variabel disiplin adalah $(0,000)$ lebih kecil dari 0,05, yang berarti bahwa hipotesis dalam penelitian ini menerima $\mathrm{H}_{a}$ dan menolak $\mathrm{H}_{0}$. Dengan demikian dapat disimpulkan bahwa hipotesis H1 "Disiplin mempunyai pengaruh positif dan signifikan terhadap Kinerja" diterima. 


\section{Uji F (Simultan)}

Berdasarkan Hasil perhitungan statistik uji $\mathrm{F}$ pada tabel diatas, diketahui nilai $\mathrm{F}_{\text {hitung }}=$ 85,186 lebih tinggi dari nilai $\mathrm{F}_{\text {tabel }}$ yaitu 3,08. Taraf signifikansi seluruh variabel bebas secara simultan $(0,000)$ lebih kecil dari 0,05 , yang berarti hipotesis dalam penelitian ini menerima $\mathrm{H}_{\mathrm{a}}$ dan menolak $\mathrm{H}_{0}$. Dengan demikian dapat disimpulkan bahwa Hipotesis 3 "Disiplin dan Motivasi mempunyai pengaruh postif dan signifikan terhadap Kinerja" diterima.

\section{Koefisien Determinasi}

Berdasarkan hasil output SPSS yang terdapat didalam tabel diatas, diketahui bahwa nilai $R$ Square $\left(\mathrm{R}^{2}\right)$ adalah sebesar 0.431 dimana nilai tersebut $R$ Square $\left(\mathrm{R}^{2}\right)$ masuk dalam kategori sedang. Sehingga, dapat disimpulkan bahwa variabel disiplin memiliki pengaruh positif terhadap kinerja dengan perolehan nilai sebesar $43,1 \%$, sedangkan sisanya yaitu sebesar $56,9 \%$ ditentukan oleh faktor-faktor lain yang tidak diteliti dalam penelitian ini.

\section{Variabel Motivasi $\left(\mathrm{X}_{2}\right)$ terhadap Kinerja $(\mathrm{Y})$}

Berdasarkan hasil output SPSS dalam tabel diatas, diketahui bahwa nilai $R$ Square $\left(\mathrm{R}^{2}\right)$ adalah sebesar 0.412 dimana nilai tersebut masuk pada kategori sedang. Sehingga, dapat disimpulkan bahwa variabel motivasi memiliki pengaruh positif terhadap kinerja dengan perolehan nilai sebesar $41,2 \%$, sedangkan sisanya yaitu sebesar $58,8 \%$ ditentukan oleh faktor-faktor lain yang tidak diteliti dalam penelitian ini.

Pengaruh Disiplin $\left(\mathrm{X}_{1}\right)$ dan Motivasi $\left(\mathrm{X}_{2}\right)$ terhadap Kinerja (Y) diketahui bahwa nilai $R$ Square $\left(\mathrm{R}^{2}\right)$ adalah sebesar 0.614 dimana nilai tersebut masuk pada kategori kuat. Sehingga, dapat disimpulkan bahwa variabel disiplin dan motivasi secara simultan memiliki pengaruh positif terhadap kinerja dengan perolehan nilai sebasar $61,4 \%$, sedangkan sisanya yaitu sebesar $38,6 \%$ ditentukan oleh faktor-faktor lain yang tidak diteliti dalam penelitian ini.

\section{Pembahasan}

Pengaruh Disiplin $\left(\mathrm{X}_{1}\right)$ terhadap Kinerja $(\mathrm{Y})$

Berdasarkan hasil analisis deskriptif pada variabel Disiplin, distribusi jawaban responden yang menjawab "sangat setuju" adalah sebanyak 287 dan bila dipersentasekan adalah sebesar $26,1 \%$, responden yang menjawab "setuju" adalah sebanyak 676 dan bila dipersentasekan adalah sebesar $61,5 \%$, responden yang menjawab "kurang setuju" adalah sebanyak 96 dan bila dipersentasekan adalah sebesar 8,7\%, responden yang menjawab "tidak setuju" adalah sebanyak 37 dan bila dipersentasekan adalah sebesar 3,4\%, sementara responden yang menjawab sangat tidak setuju adalah sebanyak 4 orang responden dan bila dipersentasekan adalah sebesar 0,4\%.

Selanjutnya, persamaan regresi sederhana yang terbentuk yaitu $\mathrm{Y}=10,492+0,656 \mathrm{X}_{1}$. Persamaan tersebut memberikan informasi bahwa nilai kinerja yang terbentuk adalah 10,492 dan setiap terjadi peningkatan satu satuan variabel disiplinakan dapat mengakibatkan peningkatan nilai kinerja sebesar 0,656 .

Selanjutnya hasil pengujian hipotesis secara parsial (uji t), diperoleh nilai $t_{\text {hitung }}$ sebesar 9,044 lebih besar dari nilai $t_{\text {tabel }}$ yaitu 1,982, dengan demikian $\mathrm{H}_{0}$ ditolak dan $\mathrm{H}_{\mathrm{a}}$ diterima. Sehingga dapat disimpulkan bahwa variabel disiplin memiliki pengaruh yang signifikan terhadap kinerja karyawan pada SMK Sasmita Jaya 1.

Kemudian hasil pengujian koefesien determinasi diperoleh nilai $R$ Square $\left(\mathrm{R}^{2}\right)$ sebesar 0,431 , sehingga dapat disimpulkan bahwa variabel disiplin mempengaruhi kinerja sebesar 43,1\% dan sisanya 56,9\% dipengaruhi faktor lain yang tidak diteliti dalam penelitian ini, hal ini membuktikan bahwa variable disiplin berpengaruh secara signifikan terhadap kinerja.

Berdasarkan hasil pengujian secara statistik dapat diketahui bahwa disiplin memiliki pengaruh positif terhadap kinerja, hal ini senada dengan penelitian terdahulu yang dilakukan oleh Astadi Pangarso dan Putri Intan Susanti yang berjudul Pengaruh Disiplin Kerja Terhadap Kinerja Pegawai Di Biro Pelayanan Sosial Dasar Sekretariat Daerah Provinsi Jawa Barat (2016:145), yang menyatakan bahwa disiplin berpengaruh 
positif terhadap kinerja karyawan sebesar 0,849.

\section{Pengaruh Motivasi $\left(\mathrm{X}_{2}\right)$ terhadap Kinerja $(\mathrm{Y})$}

Berdasarkan hasil analisis deskriptif pada variabel Motivasi, distribusi jawaban responden yang menjawab "sangat setuju" adalah sebanyak 272 dan bila dipersentasekan adalah sebesar $24,7 \%$, responden yang menjawab "setuju" adalah sebanyak 659 dan bila dipersentasekan adalah sebesar 59,9\%, responden yang menjawab "kurang setuju" adalah sebanyak 123 dan bila dipersentasekan adalah sebesar $11,2 \%$, responden yang menjawab "tidak setuju" adalah sebanyak 41 dan bila dipersentasekan adalah sebesar 3,7\% sementara responden yang menjawab sangat tidak setuju adalah sebanyak 5 orang responden dan bila dipersentasekan adalah sebesar $0 \%$.

Selanjutnya, persamaan regresi sederhana yang terbentuk yaitu $\mathrm{Y}=15,977+0,624 \mathrm{X}_{2}$. Persamaan tersebut memberikan informasi bahwa nilai kinerja yang terbentuk adalah 15,977 dan setiap terjadi peningkatan satu satuan variabel motivasi akan dapat mengakibatkan peningkatan nilai kinerja sebesar 0,624 .

Selanjutnya hasil pengujian hipotesis secara parsial (uji $\mathrm{t}$ ), diperoleh nilai $\mathrm{t}_{\text {hitung }}$ sebesar 8,698 lebih besar dari nilai $\mathrm{t}_{\text {tabel }}$ yaitu 1,982, dengan demikian $\mathrm{H}_{0}$ ditolak dan $\mathrm{H}_{\mathrm{a}}$ diterima. Sehingga dapat disimpulkan bahwa variabel motivasi memiliki pengaruh secara signifikan terhadap kinerja karyawan pada SMK Sasmita Jaya 1.

Kemudian hasil pengujian koefesien determinasi diperoleh nilai $R$ Square $\left(R^{2}\right)$ sebesar 0,412 , sehingga dapat disimpulkan bahwa variabel motivasi mempengaruhi kinerja sebesar 41,2\% dan sisanya 58,8\% dipengaruhi faktor lain yang tidak diteliti dalam penelitian ini, hal ini membuktikan bahwa variabel motivasi berpengaruh secara signifikan terhadap kinerja.

Berdasarkan hasil pengujian secara statistik dapat diketahui bahwa motivasi memiliki pengaruh secara signifikan terhadap kinerja, hal ini sesuai dengan pendapat yang dikemukakan oleh Munandar (2006:42), yang menyatakan bahwa terdapat hubungan positif antara motivasi dengan kinerja, artinya karyawan yang memiliki motivasi prestasi yang tinggi cenderung mempunyai kinerja yang tinggi, sebaliknya karyawan yang mempunyai kinerja yang rendah dimungkingkan karena motivasinya rendah.

\section{Pengaruh Disiplin $\left(\mathrm{X}_{1}\right)$ dan Motivasi $\left(\mathrm{X}_{2}\right)$ terhadap Kinerja $(\mathrm{Y})$}

Berdasarkan hasil analisis deskriptif pada variabel kinerja, distribusi jawaban responden yang menjawab "sangat setuju" adalah sebanyak 334 dan bila dipersentasekan adalah sebesar $30,4 \%$, responden yang menjawab "setuju" adalah sebanyak 639 dan bila dipersentasekan adalah sebesar $58,1 \%$, responden yang menjawab "kurang setuju" adalah sebanyak 95 dan bila dipersentasekan adalah sebesar 8,6\%, responden yang menjawab "tidak setuju" adalah sebanyak 27 dan bila dipersentasekan adalah sebesar 2,5\%, sementara responden yang menjawab sangat tidak setuju adalah sebanyak 5 orang responden dan bila dipersentasekan adalah sebesar 0,5\%.

Selanjutnya, persamaan regresi berganda yang terbentuk yaitu $\mathrm{Y}=0,230+0,485 \mathrm{X}_{1}+0,461$ $\mathrm{X}_{2}$. Persamaan tersebut memberikan informasi bahwa nilai kinerja yang terbentuk adalah 0,230 dan setiap terjadi peningkatan satu satuan variabel disiplin mempengaruhi variabel kinerja sebesar 0,485. Selanjutnya, setiap terjadi peningkatan satu satuan variabel motivasi akan dapat mengakibatkan peningkatan nilai kinerja sebesar 0,461 .

Selanjutnya hasil pengujian hipotesis secara simultan (uji F), diperoleh nilai $\mathrm{F}_{\text {hitung }}$ sebesar 85,186 lebih besar dari nilai $\mathrm{F}_{\text {tabel }}$ yaitu 3,08, dengan demikian $\mathrm{H}_{0}$ ditolak dan $\mathrm{H}_{a}$ diterima. Sehingga dapat disimpulkan bahwa variabel disiplindan motivasi secara simultan memiliki pengaruh yang signifikan terhadap kinerja karyawan pada SMK Sasmita Jaya 1.

Selanjutnya hasil pengujian koefesien determinasi diperoleh nilai $R$ Square $\left(\mathrm{R}^{2}\right)$ sebesar 0,614 , sehingga dapat disimpulkan bahwa variabel disiplin dan motivasi mempengaruhi kinerja sebesar $61,4 \%$ dan sisanya 38,6\% dipengaruhi faktor lain yang tidak diteliti dalam penelitian ini, hal ini membuktikan bahwa variabel disiplin dan motivasi berpengaruh secara signifikan terhadap kinerja. 
Berdasarkan hasil pengujian secara statistik dapat diketahui bahwa disiplin dan motivasi memiliki pengaruh secara signifikan terhadap kinerja. Hal ini senada dengan penelitian terdahulu yang dilakukan oleh Evawati Khumaedi yang berjudul Pengaruh Disiplin dan Motivasi Kerja Terhadap Kinerja Pegawai Pada Dinas Sentra Operasi Terminal PT. Angkasa Pura II (2016:66), yang berdasarkan hasil persamaan regresi yang terbentuk $\mathrm{Y}=21,015+0,396 \mathrm{X}_{1}+0,278 \mathrm{X}_{2}$ yang berarti disiplin dan motivasi secara bersamasama berpengaruh terhadap kinerja.

\section{SIMPULAN}

Disiplin berpengaruh positif dan signifikan terhadap kinerja karyawan pada SMK Sasmita Jaya 1. Hal ini dapat dilihat berdasarkan hasil uji $\mathrm{t}$ dimana diperoleh nilai $\mathrm{t}_{\text {hitung }}$ sebesar $9,044>$ nilai $\mathrm{t}_{\text {tabel }}$ yaitu 1,982 dengan taraf signifikansi $(0,000)$ lebih kecil dari $(0,05)$. Selanjutnya, persamaan regresi sederhana yang terbentuk yaitu $\mathrm{Y}=10,492$ $+0,656 \mathrm{X}_{1}$.

Persamaan tersebut memberikan informasi bahwa nilai kinerja yang terbentuk adalah 10,492 dan setiap terjadi peningkatan satu satuan variabel disiplin akan dapat mengakibatkan peningkatan nilai kinerja sebesar 0,656. Selanjutnya, berdasarkan uji koefesien determinasi dapat diketahui bahwa kemampuan variabel disiplin dalam mempengaruhi variabel kinerja adalah sebesar 43,1\% sedangkan sisanya $56,9 \%$ dipengaruhi oleh faktor lain yang tidak diteliti dalam penelitian ini.

Motivasi berpengaruh positif dan signifikan terhadap kinerja karyawan pada SMK Sasmita Jaya 1. Hal ini dapat dilihat berdasarkan hasil uji t dimana diperoleh nilai $t_{\text {hitung }}$ sebesar 8,698 > nilai $t_{\text {tabel }}$ yaitu 1,982 dengan taraf signifikansi $(0,000)$ lebih kecil dari $(0,05)$. Selanjutnya, persamaan regresi sederhana yang terbentuk yaitu $\mathrm{Y}=15,977$ $+0,624 X_{2}$.

Persamaan tersebut memberikan informasi bahwa nilai kinerja yang terbentuk adalah 15,977 dan setiap terjadi peningkatan satu satuan variabel motivasi akan dapat mengakibatkan peningkatan nilai kinerja sebesar 0,624. Selanjutnya, berdasarkan uji koefesien determinasi dapat diketahui bahwa kemampuan variabel motivasi dalam mempengaruhi variabel kinerja adalah sebesar $41,2 \%$ sedangkan sisanya $58,8 \%$, dipengaruhi oleh faktor lain yang tidak diteliti dalam penelitian ini.

Disiplin dan Motivasi berpengaruh positif dan signifikan terhadap Kinerja karyawan pada SMK Sasmita Jaya 1. Hal ini dapat dilihat berdasarkan hasil uji $\mathrm{F}$ dimana diperoleh nilai $\mathrm{F}_{\text {hitung }}$ sebesar 85,186 > nilai $\mathrm{F}_{\text {tabel }}$ yaitu 3,08 dengan taraf signifikansi $(0,000)$ lebih kecil dari $(0,05)$. Selanjutnya, persamaan regresi berganda yang terbentuk yaitu $\mathrm{Y}=0,230+0,485 \mathrm{X}_{1}+0,461 \mathrm{X}_{2}$. Persamaan tersebut memberikan informasi bahwa nilai kinerja yang terbentuk adalah 0,230 dan setiap terjadi peningkatan satu satuan variabel disiplin akan dapat mengakibatkan peningkatan nilai kinerja sebesar 0,485 . Selanjutnya, setiap terjadi peningkatan satu satuan variabel motivasi akan dapat mengakibatkan peningkatan nilai kinerja sebesar 0,461. Selanjutnya, berdasarkan uji koefesien determinasi dapat diketahui bahwa kemampuan variabel disiplin dan motivasi dalam mempengaruhi variabel kinerja adalah sebesar $61,4 \%$ sedangkan sisanya $38,6 \%$, dipengaruhi oleh faktor lain yang tidak diteliti dalam penelitian ini.

\section{PENGHARGAAN}

Ucapan terima kasih ini kami sampaikan kepada seluruh pihak yang telah membantu penyelesaian penelitian ini. Terutama untuk Kepala Sekolah SMK Sasmita Jaya 1, wakil kepala sekolah, staf, dan seluruh dewan guru.

\section{DAFTAR PUSTAKA}

Anwar, A.A. \& Mangkunegara, P. (2008). Manajemen Sumber Daya Manusia, Cetakan kelima. Bandung: PT. Remaja Rosdakarya.

Arikunto, S. (2006). Prosedur Penelitian: Suatu Pendekatan Praktik. Jakarta: Rineka Cipta.

Atmodiwirio, S. (2002). Manajemen Pelatihan. Jakarta: PT. Ardadizya Jaya.

Bangun, W. (2015). Manajemen Sumber Daya Manusia. Bandung: Erlangga.

Dessler, G. (2015). Manajemen Sumber Daya Manusia-Edisi Kesepuluh. Jakarta: PT. Indeks. Ghozali, I. (2013). Aplikasi Analisis Multivariate 
dengan Spss. Semarang: Badan Peneliti UNDIP.

Handoko, H. T. (2009). Manajemen Personalian dan Sumber Daya Manusia. Yogyakarta: BPFE.

Hasbullah. (2005). Dasar-Dasar Ilmu Pendidikan. Jakarta: PT. Raja Grafindo Persada.

Hasibuan, M. S. P. (2006). Manajemen Sumber Daya Manusia, Edisi Revisi. Jakarta: PT. Bumi Aksara.

Hasibuan. (2012). Manajemen Sumber Daya Manusia, Edisi Revisi. Jakarta: PT. Bumi Aksara.

Mahsun, M. (2009). Pengukuran Kinerja Sektor Publik, Edisi Ketiga. Yogyakarta: BPFE.

Mangkuprawira, S. (2002). Manajemen Sumber Daya Manusia. Jakarta: Ghalia.

Manulang, M. (2006). Dasar-Dasar Manajemen. Yogyakarta: Gajah Mada University Press.

Marwansyah.(2014). Manajemen Sumber Daya Manusia. Bandung: Alfabeta.

Nazir, A. (2019). Pengaruh Pelatihan dan Disiplin Kerja Terhadap Kinerja Karyawan Pada PT Surya Mustika Nusantara. Jurnal Mandiri. Vol. 3 No. 1. 150-169

Nazir, M. (2011). Metode Penelitian. Jakarta: Ghalia Indonesia.

Notoatmodjo, S. (2003). Pengembangan Sumber Daya Manusia. Jakarta: Rineka Cipta.

Tirtarahardja, U. (2005). Pengantar Pendidikan. Rineka Cipta, Jakarta.

Palan, R. (2007). Competency Management: Teknis Mengimplementasikan Manajemen SDM Berbasis Kompetensi untuk Meningkatkan Daya Saing Organisasi. Jakarta: PPM.

Raharjo, J. (2013). Paradigma Baru Manajemen Sumber Daya Manusia, Kunci Sukses Meningkatkan Kinerja, Produktivitas, Motivasi, dan Kepuasan Kerja. Tangerang: Platinum.

Riniwati, H. (2011). Mendongkrak Motivasi dan Kinerja: Pendekatan Pemberdayaan SDM. Malang: UB Press.

Rivai, V. (2011), Manajemen Sumber Daya Manusia untuk Perusahaan; dari Teori ke Praktik. Jakarta: Raja Grafindo Persada.

Rusilowati, U. (2013). Manajemen Pengetahuan Berbasis Teknologi Informasi dalam Konteks Pembelajaran Organisasi. Tangerang Selatan:
CV. Asmoro Mediatama.

Sedarmayanti. (2011). Manajemen Sumber Daya Manusia, Reformasi Birokrasi dan Manajemen Pegawai Negri Sipil, cetakan kelima. Bandung: PT. Refika Aditama.

Siagian, S. P. (2013). Manajemen Sumber Daya Manusia, Edisi I, Cetakan ke Tiga Belas. Jakarta: Bumi Aksara.

Simamora, H. (2014). Manajemen Sumber Daya Manusia, Edisi Ketiga, Cetakan Pertama. Yogyakarta: STIE YKPN.

Sinambela, P. L. (2012). Kinerja Pegawai Teori Pengukuran dan Implikasi. Yogyakarta: Graha Ilmu.

Sudarmanto. (2009). Kinerja dan Pengembangan Kompetensi SDM (Teori Dimensi Pengukuran dan Implementasi dalam Organisasi. Yogyakarta: Pustaka Pelajar.

Sugiyono. (2016). Metode Penelitian Bisnis (Pendekatan Kuantitatif, Kualitatif, R\&D). Alphabeta, Bandung.

Sugiyono.(2013). Metode Penelitian Bisnis (Pendekatan Kuantitatif, Kualitatif, R\&D). Alphabeta, Bandung.

Sumarsono, S. (2004). Metode Riset Sumber Daya Manusia. Yogyakarta: Graha Ilmu.

Supardi. (2013), Aplikasi Statistika dalam Penelitian. Jakarta: Prima Ufuk Semesta.

Supriatna, D. (2009). Modul: Pengenalan Media Pembelajaran. Bahan Ajar untuk Diklat E-Training PPPPTK, Bandung.

Sutrisno, E. (2011). Manajemen Sumber Daya Manusia. Jakarta: Kencana.

Suwatno, D. J. P. (2011). Manajemen SDM dalam Organisasi Publik dan Bisinis. Bandung: Alfabeta.

Tjutju, Y. \& Suwatno. (2008). Manajemen Sumber Daya Manusia. Bandung: Alphabeta.

Wibowo. (2016). Manajemen Kinerja, Edisi Ketiga. Jakarta: Rajawali Pers.

Wibowo. (2010), Manajemen Personalia dan Sumber Daya Manusia, Edisi Kedua. Yogyakarta: BPFE UGM.

Wiluedjeng, S. (2007). Pengantar Manajemen. Yogyakarta: Graha Ilmu. 